\title{
Evolution of a patagonian Miocene intermontane basin and its relationship with the Andean foreland: Tectono-stratigraphic evidences from the Catán Lil Basin, Argentina
}

\author{
Juan R. Franzese ${ }^{\mathrm{a}}$, Leandro D'Elia ${ }^{\mathrm{a}, *}$, Andrés Bilmes ${ }^{\mathrm{b}}$, Joaquín Bucher ${ }^{\mathrm{a}}$, Micaela García ${ }^{\mathrm{a}}$, \\ Manuel López ${ }^{\mathrm{a}}$, Martín Muravchikc, Mariano Hernández ${ }^{\mathrm{a}}$ \\ ${ }^{a}$ Centro de Investigaciones Geológicas (CIG) - CONICET, Universidad Nacional de La Plata, Diagonal 113 N 275, La Plata, B1904DPK, Argentina \\ ${ }^{\mathrm{b}}$ Instituto Patagónico de Geología y Paleontología - (CENPAT-CONICET), Boulevard Almirante Brown 2915, U9120ACD, Puerto Madryn, Chubut, Argentina \\ ${ }^{\mathrm{c}}$ Department of Earth Science, University of Bergen, Allégaten 41, N-5007, Bergen, Norway
}

A R T I C L E I N F O

\section{Keywords:}

Retro-arc foreland system

Intermontane basins

Tectono-stratigraphy

Patagonia

Andes

\begin{abstract}
A B S T R A C T
The Catán Lil Basin is an intermontane basin developed on the wedge top of the Miocene North Patagonian retroarc foreland basin. This basin is formed by the growth of a west verging thick skinned fold and thrust belt. An internal anticline divides the basin into two sub-basins: Las Coloradas and Los Remolinos, with other minor isolated depocentre (La Esperanza Syncline). Due to the structural configuration the basin evolved as a compartmentalized basin, connected with an extrabasinal drainage network. Structural and sedimentological analysis of field data enable us to determine that the basin was filled in four sequences (DS-I, DS-II, DS-III and DS-IV) that recorded three major aggradational/degradational cycles characterized by alluvial-fluvial sedimentation and a final volcanic succession of olivinic basalts. The first two sequences (DS-I and DS-II) integrate a growth wedge related to tectonic uplift and limb rotation of the main anticlines. DS-III and DS-IV were deposited under post-kinematic conditions when there was no more tectonic activity in the fold and thrust belt. There is a strong difference in composition between the first sequence DS-I and the others. DS-I is composed by volcaniclastic sandstones, conglomerates and paleosols. The two other sedimentary sequences (DS-II and DS-III) are composed of purely epiclastic material. This sedimentary succession can be defined as compound valley fill occurred under general low accommodation conditions with a progressive reduction of A/S during basin evolution. The DS-IV corresponds to a volcanic plateau associated with an upper Miocene basaltic retro-arc volcanism. A new ${ }^{39} \mathrm{Ar} /{ }^{40} \mathrm{Ar}$ age for the basalts is presented in this paper that constrains the end of deposition in the Catán Lil Basin to the Upper Miocene (8.5 Ma). After this basaltic event, the foreland turned towards an erosional by-pass system in the study area.
\end{abstract}

\section{Introduction}

The last episode of orogenic uplift along the north Patagonian Andes triggered the generation of a fold and thrust belt and a Neogene retroarc foreland basin system (Giacosa and Heredia, 2004; Orts et al., 2012). The lack of high structural relief and the strong influence of the inherited basement heterogeneities resulted in the generation of an array of partitioned basins surrounded by basement heights (Mosquera and Ramos, 2006; García Morabito et al., 2011; García Morabito and Ramos, 2012, Fig. 1). In northernmost Patagonia an example of those basins are the Aluminé, Collón Cura, Catán Lil, and Ñirihuau Basin, which are distributed in a roughly N-S trend. (García Morabito et al., 2011; Franzese et al., 2011; Ramos et al., 2014, Fig. 1). Towards the central area of Patagonia the Neogene intermontane basins were described as a broken Foreland (Picún Leufú Broken Foreland: Mosquera and Ramos, 2006; Patagonian Broken Foreland: Bilmes et al., 2013). The nature of the infill of these basins was dominated by the close interaction between sedimentation and volcanism that took place during the Miocene (Cucchi and Leanza, 2005; Franzese et al., 2011; Bilmes et al., 2014).

The knowledge of these basins is growing in recent years, although this is restricted in most cases to regional studies (Folguera and Ramos, 2011; Bilmes et al., 2013, 2014; Ramos et al., 2014; Folguera et al., 2015; Gianni et al., 2015; Echaurren et al., 2016). Some of the basins with neogene infill were generated during the Oligocene as extensional basins and subsequently inverted and reconfigured as contractional

\footnotetext{
* Corresponding author.

E-mail address: ldelia@cig.museo.unlp.edu.ar (L. D'Elia).
} 


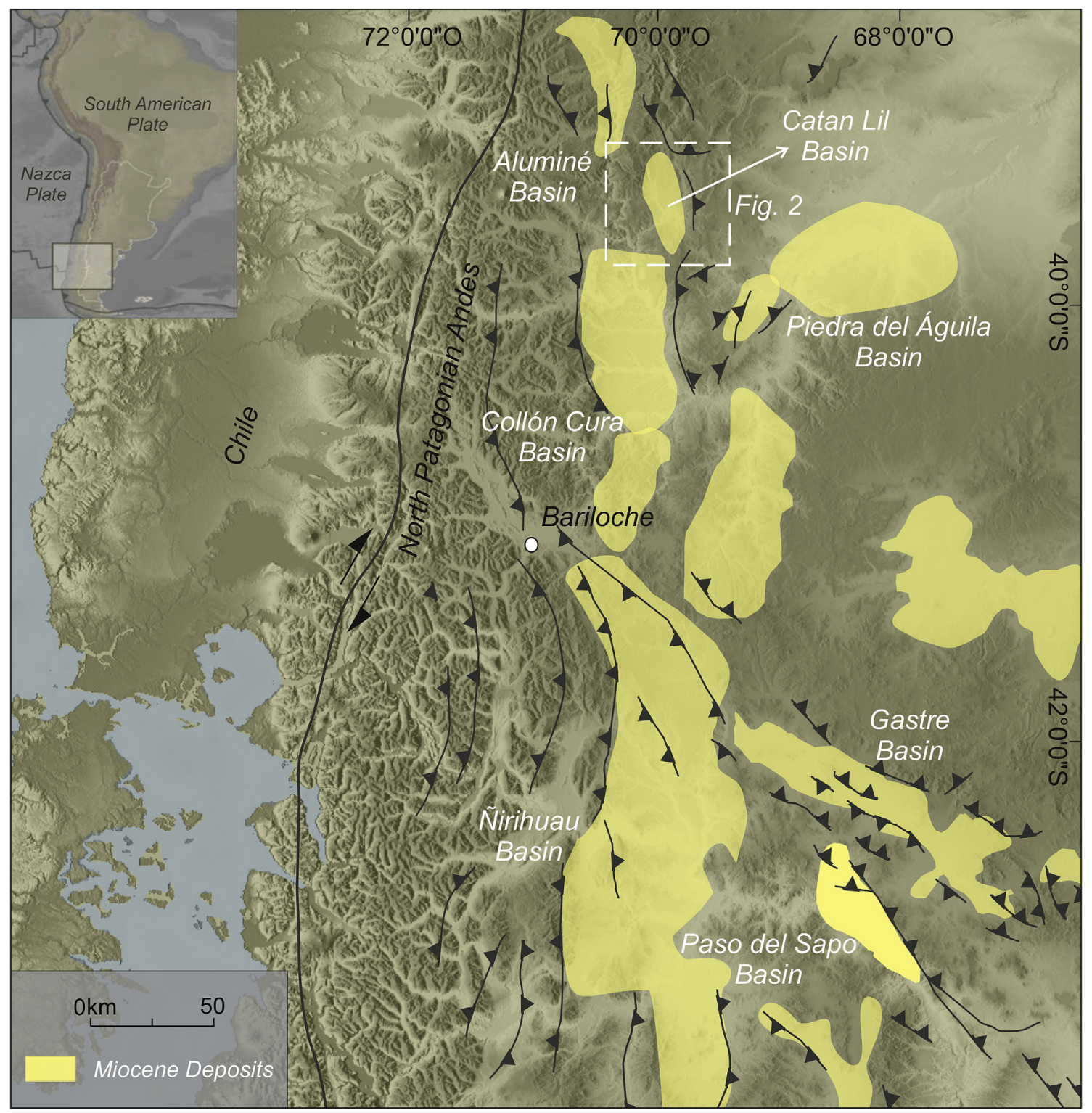

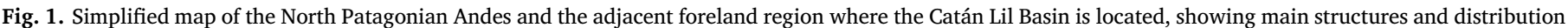
of Neogene deposits (yellow areas). (For interpretation of the references to colour in this figure legend, the reader is referred to the Web version of this article.)

basins during the Miocene along the orogenic front (e.g., Cura Mallín Basin, Folguera et al., 2003; Aluminé Basin, Franzese et al., 2011; and Auca Pan Basin, Ramos et al., 2015). To the east, the Miocene basins were generated beyond of the areas affected by the Oligocene extension (García Morabito et al., 2011; Bilmes et al., 2013). Those basins recorded deposits and processes only related to the Miocene main Andean contractional event. The Catán Lil basin is one of the best exposed contractional Neogene basins located at the wedge top of the Northpatagonian foreland (Fig. 1), which does not record evidence of previous or subsequent change of the tectonic regime (García Morabito et al., 2011; García Morabito and Ramos, 2012). Although it was described in a regional context (García Morabito et al., 2011), until now its stratigraphic and tectonic evolution is not well constrained. This basin contains valuable information that may be used to unravel the tectono-stratigraphic evolution of the intermontane wedge top basins and their relationship with subsidence and regional uplift of the Andes. Based on structural, sedimentological and geochronological studies, this contribution aims to analyze the structural configuration, the generation of accumulation space and the tectono-stratigraphy of the basin infill, in order to contribute to the understanding of the basin evolution processes in the Northpatagonian Andean foreland system.

\section{Geological setting}

The Catán Lil Basin is a $400 \mathrm{~m}$ thick intermontane basin generated during a Miocene Andean contractional episode (García Morabito et al., 2011). The basin is located between $39^{\circ} 28^{\prime}-39^{\circ} 48^{\prime}$ SL and $70^{\circ} 29^{\prime}$ $70^{\circ} 44^{\prime}$ WL (Fig. 1), several kilometres inboard of the deformational front (Mosquera and Ramos, 2006). It was defined as a small intermontane piggy-back basin developed between two anticlines associated with a west-verging thick-skinned fold-and-thrust belt (García Morabito et al., 2011, Fig. 2a). These authors constrain the age of the basin between 13 and 8 and $\sim 4.3 \mathrm{Ma}$ according to preexisting radiometric data. The pre-Neogene stratigraphy of the study area consists of a Paleozoic crystalline basement, a Mesozoic continental-marine sedimentary succession that forms part of the Neuquén Basin, an extensional retro-arc basin developed at the western margin of Gondwana in Mesozoic times (Franzese and Spalletti, 2001; D'Elia et al., 2012), and Paleogene volcanic deposits of the Rancahue Formation (Cucchi and Leanza, 2005). The Neuquén Basin infill exposed in the study area can be divided into 


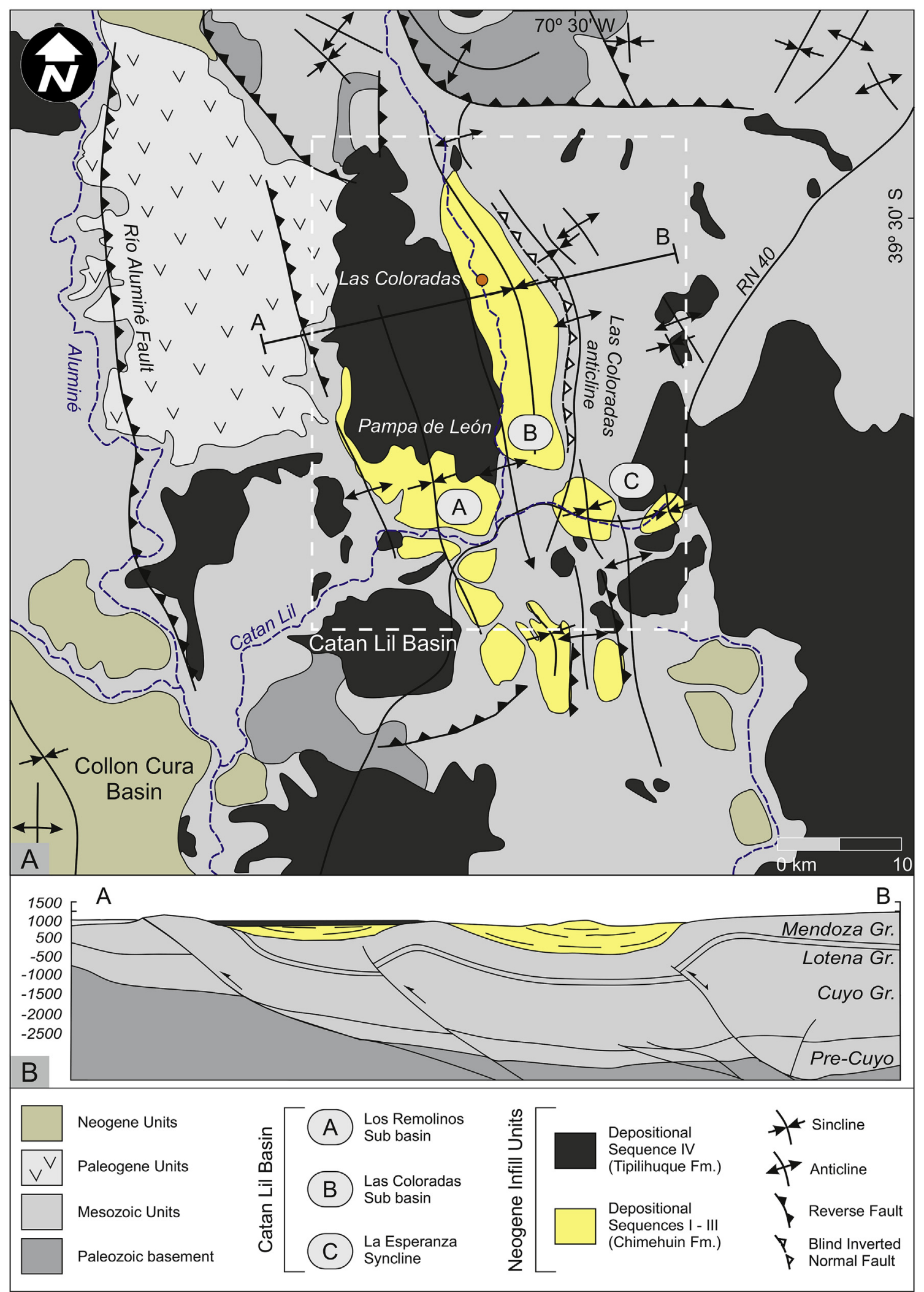

Fig. 2. a) Geologic map of the study area (modified from, D'Elia et al., 2012; Garcia Morabito et al., 2011, b) cross-sections of the Catán Lil Basin carried out from interpreted-seismic Line 93-114 in García Morabito et al. (2011) and new dataset surveyed in this study.

two units: the Lower-Middle Jurassic deposits (Cuyo Group) and the Upper Jurassic-Lower Cretaceous deposits (Mendoza Group; Gulisano et al., 1984; Vergani et al., 1995; Legarreta and Uliana, 1996). The Mesozoic section is more than 2.500 m thick.
The Neogene infill of the Catán Lil Basin started after a major hiatus of almost $100 \mathrm{Ma}$. It is grouped in two units: a) the Chimehuin Formation (Turner, 1976; Cucchi and Leanza, 2005), composed of ignimbrites, fluvial conglomerates and sandstones with levels of paleosols 
(Cucchi and Leanza, 2005; García Morabito et al., 2011); and b) the Tipilihuque Formation, formed by basaltic lava flows that cover the Chimehuin Formation (Fig. 2a and b) as well as the basement rocks of the basin. Based on stratigraphic relationships the Chimehuin Formation was constrained to the Miocene (Cucchi and Leanza, 2005; Ramos, 2013), whereas the Tipilihuque Formation, based on geochronological data, was constrained to the late Miocene-Pliocene (Vatuone and Latorre, 1988; Ré et al., 2000). Finally, Quaternary deposits are constrained to alluvial and fluvial facies and minor lava flows deposited mainly along the active drainage network (Cucchi and Leanza, 2005).

\section{Methodology}

To address a high resolution tectono-stratigraphic evolution of the Neogene Catán Lil Basin, structural and geological mapping combined with sedimentary studies were developed. In order to determine the lateral and vertical variation of the infill, ten sedimentary sections accompanied with facies analysis were performed. To analyze the internal patterns of the Neogene infill, unconformity surfaces of different hierarchy were recognized. The results are organized in sedimentary columns and stratigraphic correlation panels. ${ }^{39} \mathrm{Ar} /{ }^{40} \mathrm{Ar}$ geochronological analysis on plagioclase from a basaltic lava flow at the top of the study succession was performed to constrain the depositional time of the intermontane basin. Analysis was carried out in Actlabs (Canada) by standard methodology.

\section{The catán lil basin}

The Catán Lil Basin is well exposed along the middle section of the Catán Lil River (García Morabito et al., 2011, Fig. 2a). It is configured by a regional NNW- and N-trending asymmetric anticlines developed in the Mesozoic succession that delimited two $\sim \mathrm{N}$-trending synclines of up to $15 \mathrm{~km}$ long and around of $\sim 7 \mathrm{~km}$ wavelength. The boundary anticlines are west-verging forced folds (i.e., fault-propagation folds) with gentle plunging to the south, which are formed by the contractional reactivation of rift-related Mesozoic normal faults related to the rifting of the Neuquén Basin (García Morabito et al., 2011, Fig. 2a). The Eastern boundary of the basin is marked by the Las Coloradas anticline that exposed the Lower Cretaceous rocks of the Mendoza Group up to 1271 m.a.s.l. The western limb of this anticline is constituted by highinclined to overturned strata, whereas the eastern limb is subtly inclined around $15^{\circ}$ (Fig. 2b). To the west, the boundary of the basin is marked by an uplifted basement block, flanked by a western major thrust fault (the Río Aluminé fault; Fig. 2a). There is not record of Miocene deposits westwards of the Río Aluminé fault. The northern boundary of the basin is limited by the northernmost extension of the syncline, where it reaches the closure. An interior anticline compartmentalizes the Catan Lil basin into two depocentres: Las Coloradas subbasin, to the E, and Los Remolinos sub-basin, to the W (Fig. 2a). The central anticline presents also a NNW-trending axis and plunge to the south, although it is narrower than the Las Coloradas anticline. To the east of Las Coloradas sub-basin, some minor synclines with a thin Neogene infill were developed (i.e., La Esperanza syncline; Fig. 2a). To the south, Las Coloradas and the central anticlines converge, causing the integration of both sub-basins.

The two sub-basins show some differences in infill thickness as well as in stratigraphy. Las Coloradas sub-basin corresponds to the main depocentre of the basin, in which the Chimehuin Formation reaches its major thickness of up to $300 \mathrm{~m}$ (Figs. 2 and 4). In Las Coloradas subbasin, the basal part of the Chimehuin Formation shows a series of progressive unconformities developed over the rotated western limb of the Las Coloradas anticline (García Morabito et al., 2011, Fig. 3a). To the north, the infill of the basin progressively decreases in thickness, onlaping over the pre-Neogene rocks (Fig. 2b). In Los Remolinos subbasin, between the western boundary and the interior high created by the central anticline, the thickness reaches $200 \mathrm{~m}$ and the Chimehuin
Formation is covered by basaltic lavas of the Tipilihuque Formation (Fig. 2b).

\section{Tectono-stratigraphic analysis and facies model of the catán lil basin}

The infill of the Catán Lil basin is composed of sedimentary and pyroclastic rocks integrated within the Chimehuin Formation and by the basaltic lavas of the Tipilihuque Formation. The Chimehuin Formation is characterized by volcaniclastic deposits and epiclastic sandstones and conglomerates interbedded with siltstones that present different degree of paleosol development. Based on the recognition of three internal unconformities, the Neogene infill was divided in four Depositional Sequences (Table I), named as: DS-I, DS-II, DS-III (corresponding to the Chimehuin Formation) and DS-IV (corresponding to the Tipilihuque Formation; Figs. 2 and 3).

\subsection{Depositional sequence I (DS-I)}

At the base the DS-I is limited by an angular unconformity over the pre-Neogene rocks and above by an erosive unconformity with either the depositional sequence II or III (Fig. 3a). The DS-I is mainly preserved as a growth wedge in the synclines and, to a lesser extent, at the hinge position of the eroded anticlines (Fig. 2b). In the frontal limb of the Las Coloradas anticline the $D S-I$ is characterized by a progressive decreasing in bedding dip towards the top, from overturned strata to $\sim 25^{\circ}$ (Fig. 3b), defining it as a syn-kinematic sequence related to the growth of the Las Coloradas anticline. The DS-I is represented by fine ash-rich paleosol strata and volcaniclastic tuffaceous sandstones interbedded with epiclastic conglomerates. At the base, pyroclastic lapillituff and tuff deposits are recorded (Fig. 4).

The $D S-I$ is largely developed in Las Coloradas and Los Remolinos sub-basins as well as in the small and isolated depocentre occurred to the southeast of the study area (La Esperanza syncline; Fig. 2a). The internal stratigraphy of $D S$-I is variable between and inside of the Catán Lil sub-basins. In the eastern border of Las Coloradas sub-basin DS-I is mainly composed of a thick succession, up to $\sim 200 \mathrm{~m}$ thick, of pebbly tuffaceous sandstones that are laterally and vertically interbedded with lensoidal epiclastic conglomerate bodies (Fig. 4a and b and 5a, b and c). The pebbly tuffaceous sandstone levels are massive to diffusely stratified, moderately sorted and medium to coarse grained. Individual beds are laterally persistent and consist of vertically amalgamated tabular bodies between 1 and $5 \mathrm{~m}$ thick (Figs. 4a and 5a). The lensoidal conglomerate bodies present concave bases and planar tops with tens of metres width and up to $2 \mathrm{~m}$ thick. They are composed of moderate-to well-sorted grain-supported, fine-grained, epiclastic conglomerates with horizontal stratification or planar cross stratification (perpendicular to the margin bodies) or massive (Fig. 5b). The clastic composition is dominated by volcanic and sedimentary clasts derived from the Mesozoic Neuquén Basin infill.

The absence of tractional structures or diffusive stratification with gradational contacts in the pebbly tuffaceous sandstone deposits suggests that tabular bodies resulted from the rapid, progressive aggradation of either debris flows or hyperconcentrated flows (Smith, 1986). This facies represents the main transport and depositional process involved within DS-I in Las Coloradas sub-basin. The lensoidal conglomerate bodies represent shallow, multi-storey or single-storey, broad ribbons (Gibling, 2006), filled mainly by deposits attributed to bedload transport from stream flows (Miall, 1996). The dominance of gravity sheet flow deposits with locally shallow lenticular channel bodies suggests deposition in a proximal alluvial-fluvial scenario, with coeval episodic supply of ash-volcaniclastic materials, indicating the occurrence of an apron sedimentary environment (Smith, 1991).

At the central part of the Las Coloradas sub-basin the DS-I shows the same composition but a different facies arrangement than at the eastern border. It is mainly constituted by up to $50 \mathrm{~m}$ succession of 


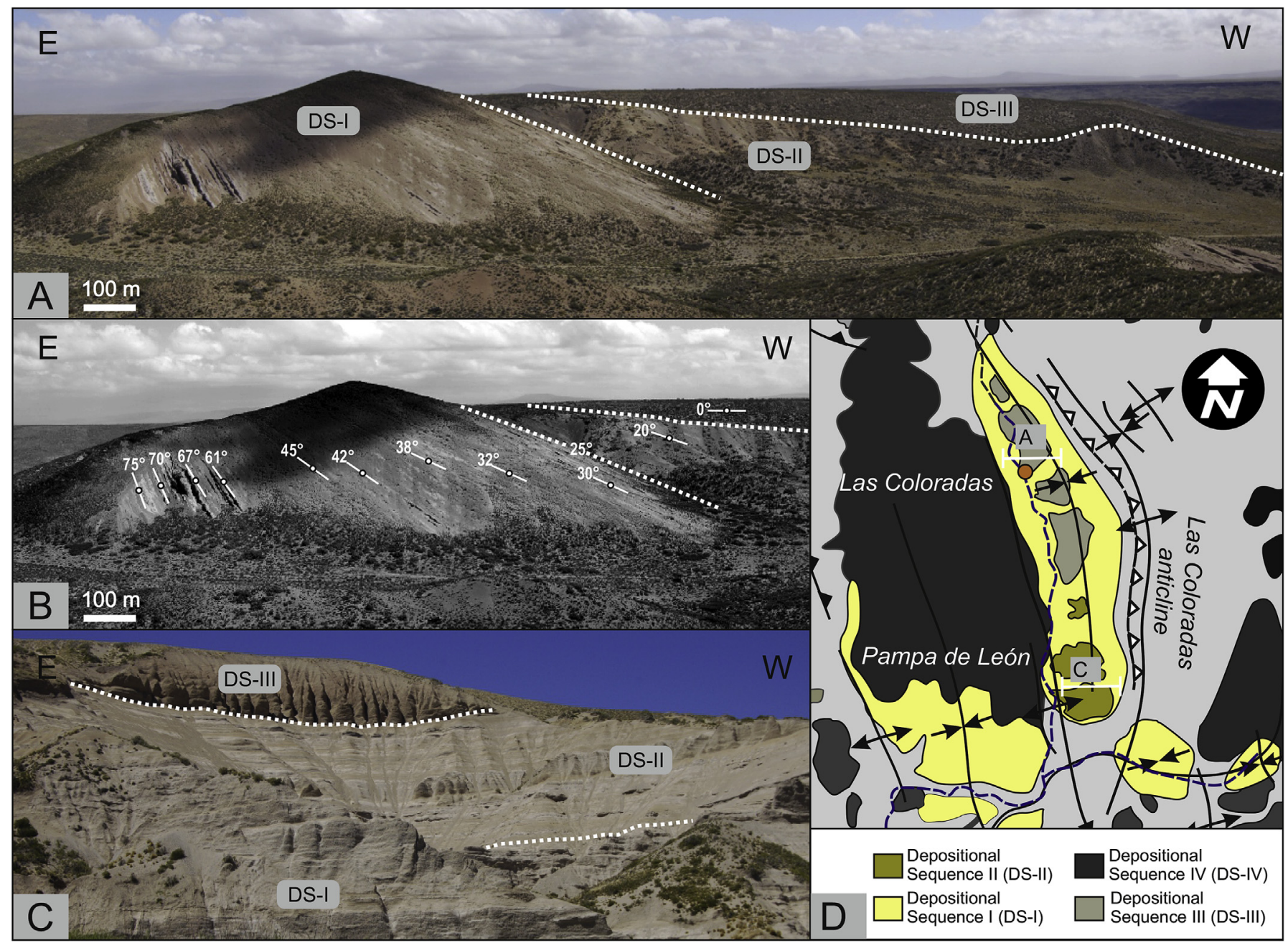

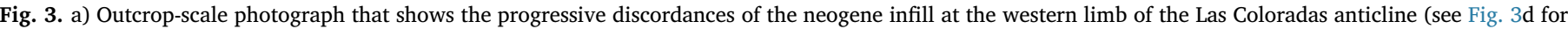

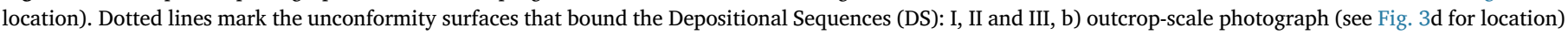

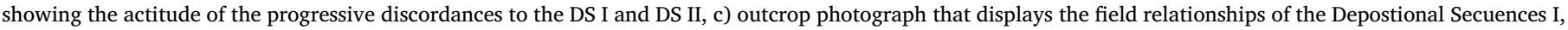
II and III, d) detailed geologic map of the Catán Lil basin with the locations outcrops photographs in Fig. 3a, b and c.

epiclastic-volcaniclastic conglomerates disposed in sheet bodies (Fig. 4a, b and d and 5c). The conglomerate sheet bodies are composed of moderately sorted (with low tuffaceous matrix), clast-support, fine conglomerates of tens of metres width and up to $0.3 \mathrm{~m}$ thick with horizontal stratification and imbricated clasts (Fig. 5 c).The conglomerate beds are vertically stacked with sharp lower strata limits. This succession internally presents isolated, lensoidal bodies of up to $5 \mathrm{~m}$ width and $1 \mathrm{~m}$ thick, constituted of either conglomerates and/or tuffaceous sandstones (Fig. 4a and b and 5c). The conglomerate facies of the lensoidal bodies is composed of moderately to well sorted, clastsupport, fine conglomerates with horizontal stratification, whereas sandstone facies are coarse-grained, moderately sorted with horizontal to cross stratification. The orientation of the channels axis as well as palaeocurrent directions derived from clast imbrication and from planar and trough cross-stratification, indicate that sedimentary deposits were transported from north to south (Fig. 4a and d). The DS-I facies association corresponds to dilute high discharge conditions stream flow deposits related to a gravelly-dominated, bedload fluvial systems (Miall, 1996). The nature and position of these facies associations indicates that a longitudinal drainage system worked in the central part of the Las Coloradas sub-basin synchronous with the DS-I apron facies association observed at the eastern border of the sub-basin.

In Los Remolinos sub-basin the DS-I conforms the entire infill. At the western boundary of this sub-basin it is composed of a facies association of pebbly tuffaceous sandstones, laterally and vertically interbedded with lensoidal epiclastic conglomerate bodies. The clast composition of the conglomerates shows provenance from the neighbour uplifted Mesozoic sedimentary succession. Pebbly tuffaceous sandstone facies shows massive structure with tabular geometry, whereas epiclastic conglomerate facies presents horizontal diffuse stratification or cut and fill structure. Based on these features, the DS-I at the western boundary of the Los Remolinos sub-basin represents a volcaniclastic apron attached to the uplifted margin (see DS-I at Las Coloradas sub-basin), configured by tuffaceous hyperconcentrated flow deposits or debris flow deposits, and shallow channels that provided the epiclastic material (see Smith, 1991). In the interior and eastern boundary of this subbasin the $D S-I$ is constituted by tuffaceous siltstone deposits interbedded with lensoidal tuffaceous sandstones (Table 1; Fig. 5d). The tuffaceous siltstone deposits are laterally extensive tabular units from 2 to $5 \mathrm{~m}$ thick. These deposits show reddish horizons, with abundant pedogenic structures, such as rhizoliths, mottles and nodules, as well as Celiforma and Coprinisphaera sp. trace fossils (Fig. 5e and f). The lensoidal tuffaceous sandstones interbedded with the fine-grained deposits are isolated bodies $4 \mathrm{~m}$ width and up to $2 \mathrm{~m}$ thick. They are composed of wellsorted, medium tuffaceous sandstones with trough cross stratification (Figs. 4c and 5d). The tuffaceous siltstone deposits represent floodplain sedimentation coeval with ash volcanic supply, whereas the lensoidal sandstone bodies correspond to ribbon channels associated with a 


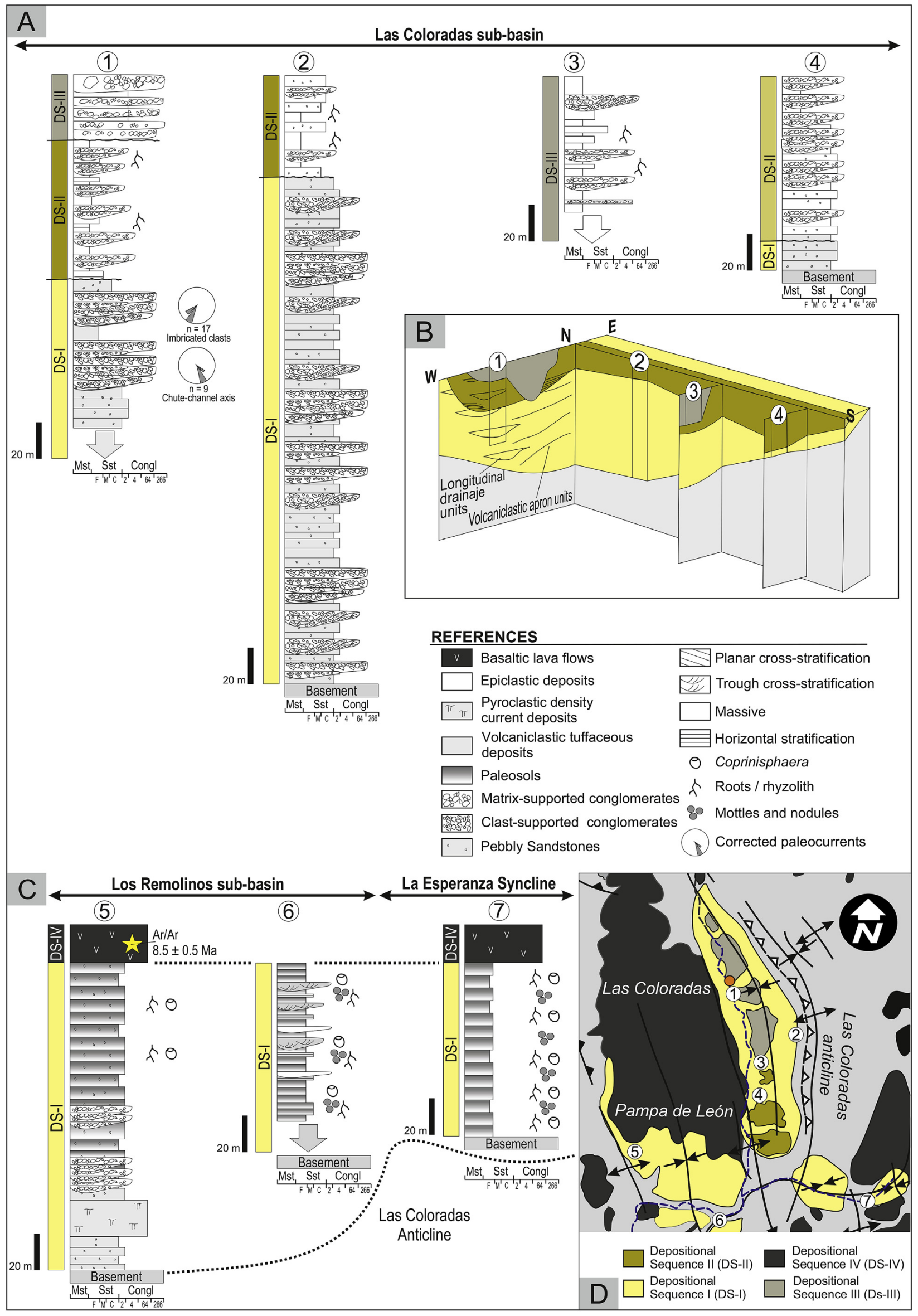

(caption on next page) 


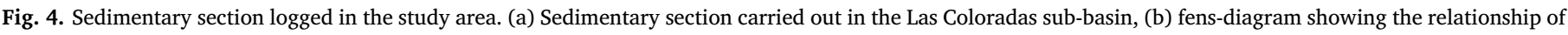

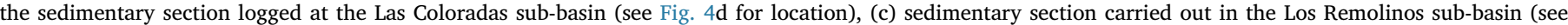
Fig. 4d for location), (d) detail geological map of the study area showing profiles location.

sandy bedload fluvial system (Miall, 1996). This facies association suggests a mixed-load fluvial system in a high aggradational context (Shanley y McCabe, 1994). The succession of volcaniclastic paleosols indicates episodic sedimentary supply to the system possibly related with volcanic activity.

\subsection{Depositional sequence II (DS-II)}

The DS-II is only observed in Las Coloradas sub-basin. It overlies the $D S-I$ through an angular unconformity that marked an abrupt shift of the sedimentation toward the centre of the sub-basin (Fig. 4; Fig. 6a). It shows a wedge-shape geometry and onlap relation with the DS-I. This sequence also presents growth strata with a range of dip between the beds from $30^{\circ}$ to $\sim 5^{\circ}$, indicating that deposition proceeded also in a syn-kinematic condition. The DS-II records a change in the sedimentary composition marked by the disappereance of the volcaniclastic component that is common in DS-I. The DS-II is constituted by epiclastic siltstone and sandstone facies which are interbedded with conglomerate-dominated bodies with volcanic and sedimentary clasts provided from the neighbour uplifted areas. The siltstone and sandstone facies are composed of tabular bodies from $0.1 \mathrm{~m}$ to up to $1 \mathrm{~m}$ thick. Siltstone facies is massive to laminated, brownish deposits (Fig. 4a and b and 6b), whereas the sandstone facies is composed of either massive to horizontally stratified, moderately sorted, medium to coarse-grained, pebbly sandstones (Fig. 4a). The conglomerate-dominated bodies present tabular large-scale geometry, with lower erosional boundaries. They are 0.5 up to $1.5 \mathrm{~m}$ thick and tens of metres width. They consist of amalgamated, poorly to moderately-sorted, clast-supported fine conglomerates, with horizontal or low-angle planar cross stratification (Figs. 4a and 6d). To a lesser extent, cut and fill structures with horizontal to cross-stratified medium to coarse sandstones in lenticular bodies occur (Fig. 6e). Based on the absence or low-quantity of siltstone and pebbly sandstone deposits within the conglomerate facies, we interpret that siltstone and pebbly sandstone deposits are not genetically related to the conglomerate-dominated tabular large-scale bodies. The siltstone and pebbly sandstone deposits are interpreted as decantation or high discharge flash-flood, respectively, occurred in distal alluvial plains (Kelly and Olsen, 1993). The conglomerate-dominated tabular large-scale bodies are interpreted as multi-lateral, fluvial channel-belt deposits, where the bedload material was mainly transported as diluted flows (Miall, 1996; Gibling, 2006).

\subsection{Depositional sequence III (DS-III)}

The DS-III is also only recorded in Las Coloradas sub-basin along the axial trend of the regional syncline that forms the depocentre (Fig. 3d). It is limited below by an erosive unconformity over the DS-I and DS-II. The DS-III is a subhorizontal sequence, internally constituted by a pattern of parallel strata that show onlap relationship over the previous depositional sequences (Fig. 3a and c). Based on this observation and the lack of other syn-kinematic feature the DS-III corresponds to a postkinematic sequence, developed after the Las Coloradas anticline was entirely formed. The DS-III shows a wedge shape decreasing the thickness from north to south, from $70 \mathrm{~m}$ to $40 \mathrm{~m}$ thick. It is constituted by two units separated trough an erosional unconformity. The lower unit of the DS-III (LDS-III) is composed by a succession of up to $40 \mathrm{~m}$ thick conglomerate-dominated deposits (Fig. 4a). This facies is composed of fine to medium-grained, massive conglomerates. They are clast to matrix-supported, poorly to moderately sorted and are presented as amalgamated tabular bodies of 0.5-1.5 m thick, (Fig. 6c). Interbedded with this facies, isolated lensoidal bodies of up to $3 \mathrm{~m}$ wide and $0.5 \mathrm{~m}$ thick composed of poorly-to moderately-sorted pebbly sandstones with horizontal stratification occur (Fig. 6f). The composition of the clastic material is polymictic including lithic fragments of plutonic and volcanic rocks as well as sedimentary clasts derived from the Neuquén Basin infill. Based on this facies association the LDS-III is interpreted as a succession of non-cohesive debris flow deposits (Coussot and Meunier, 1996) and channelized flash flood deposits occurred in a proximal alluvial system (Blair and McPherson, 1994).

The upper section of the DS-III (UDS-III) is composed of conglomerate-sandstone sheet bodies interbedded with tabular fine-grained deposits. The conglomerate-sandstone sheet deposits are up to $3 \mathrm{~m}$ thick and tens of metres width. They are internally composed of lenticular to tabular amalgamated bodies with erosional lower boundaries and minor cut and fill structures, composed of moderately-sorted, fine conglomerates and coarse-grained sandstones. These facies present planar to through cross stratification and horizontal stratification (Figs. 4a and 6f). The tabular fine-grained deposits, interfingered with the conglomerate-sandstone sheet deposits, present sharp erosional bases and thickness from centimetres to up to $5 \mathrm{~m}$. They are composed of massive to laminated reddish siltstone or fine-grained sandstones. The absence of fine-grained facies within the sandy-gravely fluvial deposits suggests that they are not genetically related. The conglomerate-sandstone sheet deposits are interpreted as bedload fluvial channelbelt deposits (Gibling, 2006) while the fine-grained deposits are interpreted as distal alluvial plain deposits (Kelly and Olsen, 1993).

\subsection{Depositional sequence IV (DS-IV)}

The DS-IV (Tipilihuque Formation) is only deposited in Los Remolinos sub-basin, where amalgamated lava flows filled the entire depositional space. This sequence represents the final infill of the Catán Lil Basin. No tectonic structures synchronous or after the formation of the $D S-I V$ were recognized. It is limited below by an erosive unconformity over the DS-I. In the eastern margin of the sub-basin, the interior anticline that separated the two sub-basins of the Catán Lil Basin was partly eroded and the $D S-I V$ covers the bedrock through an angular unconformity (Figs. $2 \mathrm{~b}$ and $7 \mathrm{a}$ and $\mathrm{b}$ ). The top of $D S-I V$ represents the older and highest geomorphologic surface of the study area. It shows a subhorizontal and flat shape and is located up to 1365 m.a.s.l. at the northern boundary of the basin and $\sim 1100$ m.a.s.l. in the southernmost limit, with a gradient of $<0.5^{\circ}$ to the southeast. The main lava facies corresponds to coherent and tabular olivine basalt. This facies is associated into different amalgamated lava units that conforms the olivine basaltic plateau of Pampa del León (Fig. 7b and c). This plateau presents a maximum thickness of $35 \mathrm{~m}$ over an area of $\sim 250 \mathrm{~km}^{2}$. In order to constrain the upper age of the Catán Lil Basin, a ${ }^{39} \mathrm{Ar} /{ }^{40} \mathrm{Ar}$ age was carried out (Fig. $7 \mathrm{~d}$ ), dating this units to $8.5 \pm 0.5$ Ma. This age is compatible with other radiometric ages obtained on a more regional scale for the basaltic lava plateau that covered the basins related to the main Andean contraction in this part of the Northpatagonian Andes (Franzese et al., 2011).

\section{Discussion}

The tectono-stratigraphic study over the recorded field data allowed organizing the infill in four depositional sequences (Table I). Based on the facies analysis, DS-I, DS-II and DS-III are interpreted as alluvialfluvial sequences ocurred under different sediment supply, tectonic conditions as well as distribution and staking patterns inside and between the sub-basins. The DS-IV corresponds to a volcanic plateau associated with a late Miocene basaltic retro-arc volcanism. 


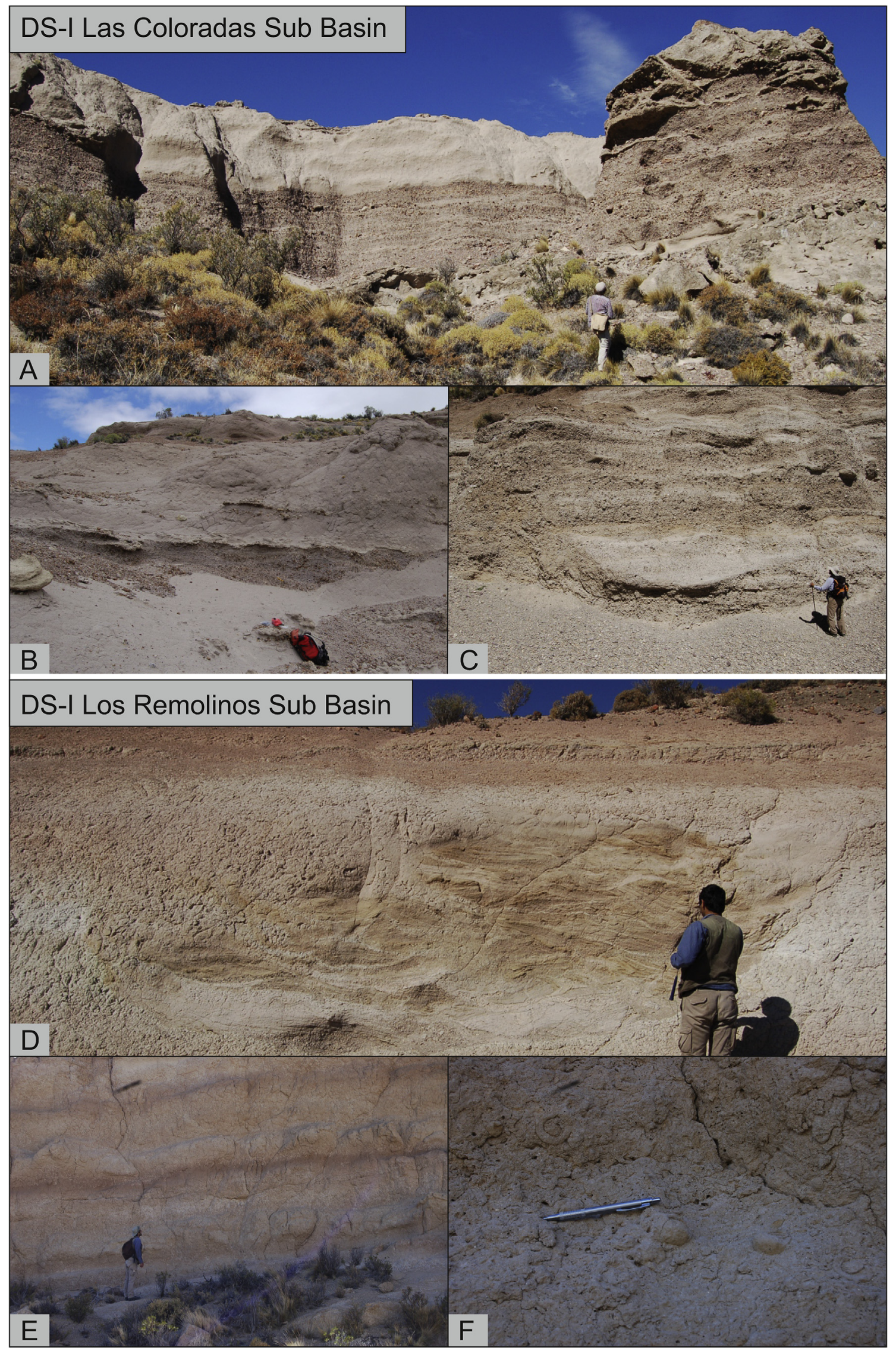

Fig. 5. Depositional Sequence I. a) Volcaniclastic facies of the apron system (upper part) interbedded with mixed epiclastic-volcaniclastic, gravelly-dominated facies of the bedload, sheet channels (lower part) occurred in the axial position of the basin, b) apron facies, c) detail of longitudinal gravels deposits, d) mixed load fluvial system, channel and flood plain, e) paleosol succession at the la esperanza syncline, f) detail of paleosol feature with Coprinisphaera sp. trace fossils. 
Structural and stratigraphic data obtained indicate that $D S-I$ and $D S$ II are syntectonic deposits. They integrate a syn-kinematic clastic wedge related to the two main growth synclines that form the Catán Lil Basin. The DS-I record volcaniclastic aprons attached to the limbs of the limiting anticlines. The observations carried out along the axis of the eastern syncline (Las Coloradas sub-basin) indicate that the progressive infill of the basin was contemporaneous with the transfer of the sedimentary materials by a longitudinal fluvial system from the initial stage of the basin (Fig. 8). The difference in grain-size of the volcaniclastic facies, combined with the occurrence of epiclastic sedimentation and the development of paleosols, not only indicate the episodic character of the volcanic supply to the system (see Smith, 1991), but also that the volcanic clasts were completely reworked and reorganized within the system. This evidence combined with the small occurrence or absence of primary pyroclastic deposits that indicate syn-eruptive deposition (beyond the ignimbrite units recorded towards the base of the DS-I), suggest long periods of residence of volcaniclastic materials within the system, together with the supply of a great volume of volcaniclastic materials derived mainly from erosion, resedimentation and reworking of pyroclastic units (see Major et al., 1996; Rodolfo et al., 1996; Scott et al., 1996; Manville et al., 2009).

During this stage, the aggradational pattern in the volcaniclastic aprons, as well as the association of isolated gravel/sand ribbon channels and overbank fine materials in Los Remolinos sub-basin (Table I) are indicative of an aggradational context under an equilibrium between accommodation space and sediment supply (see Smith, 1991, Wright and Marriott, 1993, Shanley and McCabe, 1994; Marriott, 1999). Difference in sedimentary infill between Las Coloradas and Los Remolinos sub-basins reflects the difference in gradient associated to the structural morphology of the basin, with its maximum topographic high at the eastern border.

The syn-kinematic DS-II in Las Coloradas sub-basin occurred after a period of valley incision and the localization of the through-going fluvial system within valley margins (Fig. 8b). The depositional systems recorded in the DS-II present different implications related to the coupling effect of the tectonic and volcanic controls. The DS-II is a synkinematic sequence deposited during a final stage of limb rotation of the Las Coloradas anticline at the eastern margin of the basin. The boundary between $D S-I$ and $D S-I I$ is related to truncation and erosion of $D S-I$ as well as the bedrock during the migration of the depositional area towards the interior of the syncline and the progressive onlap of $D S$-II over DS-I. DS-I and DS-II can be described as proximal to distal offstructure wedges (Fig. 4b; Patton, 2004). This implies a reduction in the area of deposition trough time. The strong contrast in composition between $D S$-I and DS-II (i.e., volcaniclastic vs epiclastic), with the abrupt waning of the volcaniclastic supply would have a decisive influence on the change of the depositional geometry of DS-II. The geomorphic and stratigraphic evidence indicate that the whole basin was filled near capacity by the end of DS-II. The cyclic alternation of a laterally extended gravelly bedload, sheet channel fluvial system with deposits of distal alluvial plain environment that characterized the DSII, occurred when the basin progressively changes from a syn-kinematic to a post-kinematic stage. Progressive decreasing in deformation and small scale cyclic arrangements between alluvial and fluvial environments could be interpreted as a result of autocyclic variations or climate factors. The alternation of these sedimentary environments does not show a progradational pattern, indicating continued aggradational conditions during deposition and equilibrium between accommodation space and sediment supply.

DS-III in Las Coloradas sub-basin was deposited above a regional erosional unconformity that marks the end of the contractional deformation in the study area. The surface boundary below DS-III implies a deep incision cutting the DS-I/DS-II wedge at the axis of the syncline (Figs. 4d and 6a). Its horizontal disposition and its relation of onlap over $D S-I$ and $D S$-II are characteristic of a post-kinematic sequence. The aggradational behavior of the DS-III following this second episode of 


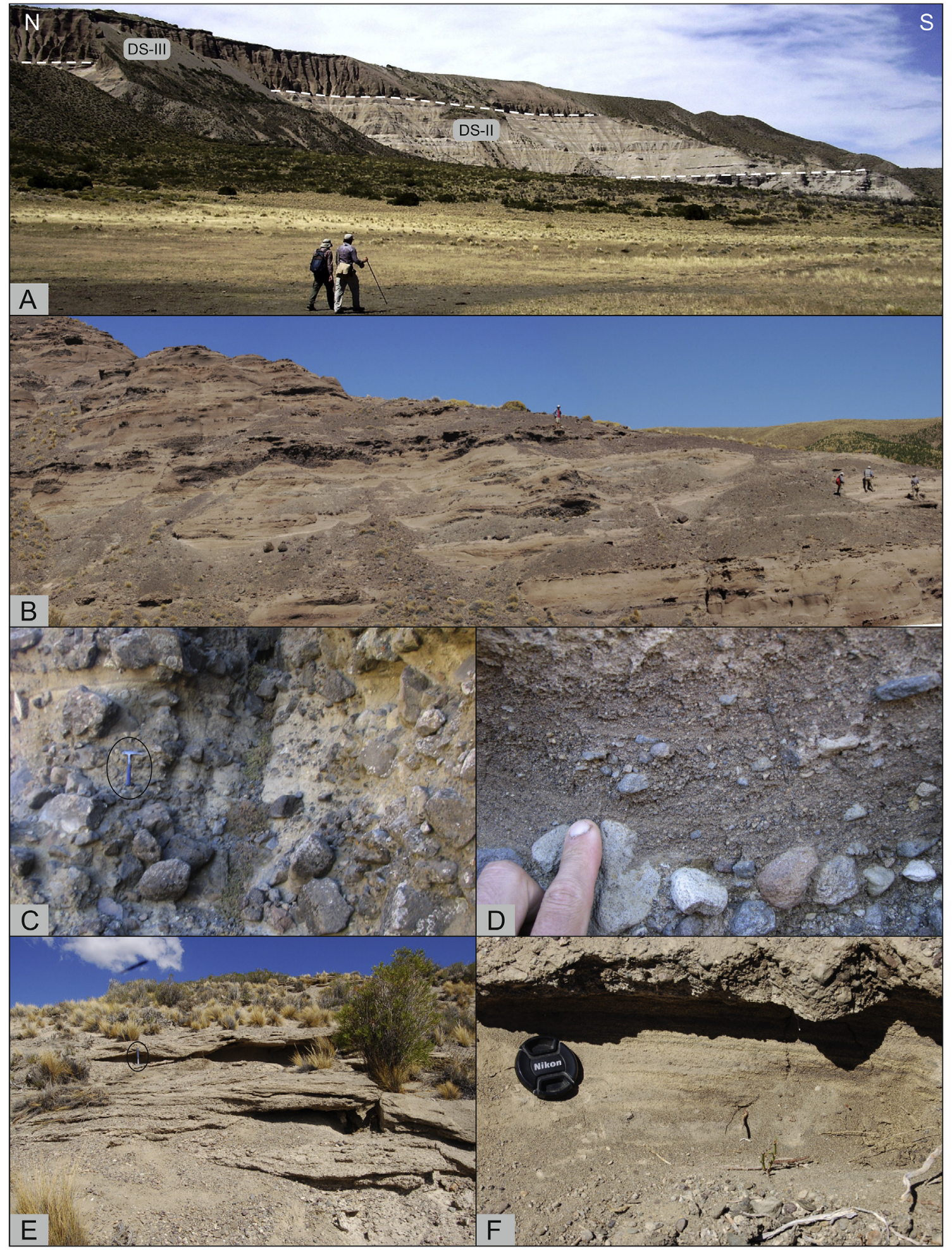

Fig. 6. Depositional Sequence II and III. a) Outcrop-scale photograph that shows the vertical relation between Depositional Sequences, b) detail of Despositional Sequence II constituted by siltstones and sandstones interbedded with conglomerate dominated bodies, c) conglomerate dominated deposits of the Depositional Sequence-III (lower part) with minor intercalated lensoidal sandstones bodies. d) detail of tabular fine grained deposits, constituted by poorly-to moderately-sorted pebbly sandstones, e) detail of conglomerated bodies with tabular to large-scale lensoidal geometry, with lower erosional boundaries, f) massive to horizontally stratified sandstones.

incision indicates another stage of uprising of the stratigraphic base level with a huge transference of coarse gravel material to the basin (Figs. 4a and 6c). The DS-III started with the deposition of laterally extended coarse alluvial sedimentation (LDS-III), indicating a progradation of the system with regards to the sedimentary facies of the
DS-II (Fig. 8b). This event is related to the integration of the drainage network during the post-tectonic stage and a crisis in the generation of accommodation space (i.e., low accommodation space/sediment supply ratio), that driven diffusion of gravelly-facies along the system (see Allen and Allen, 2013). The DS-III follows with the sedimentation of 


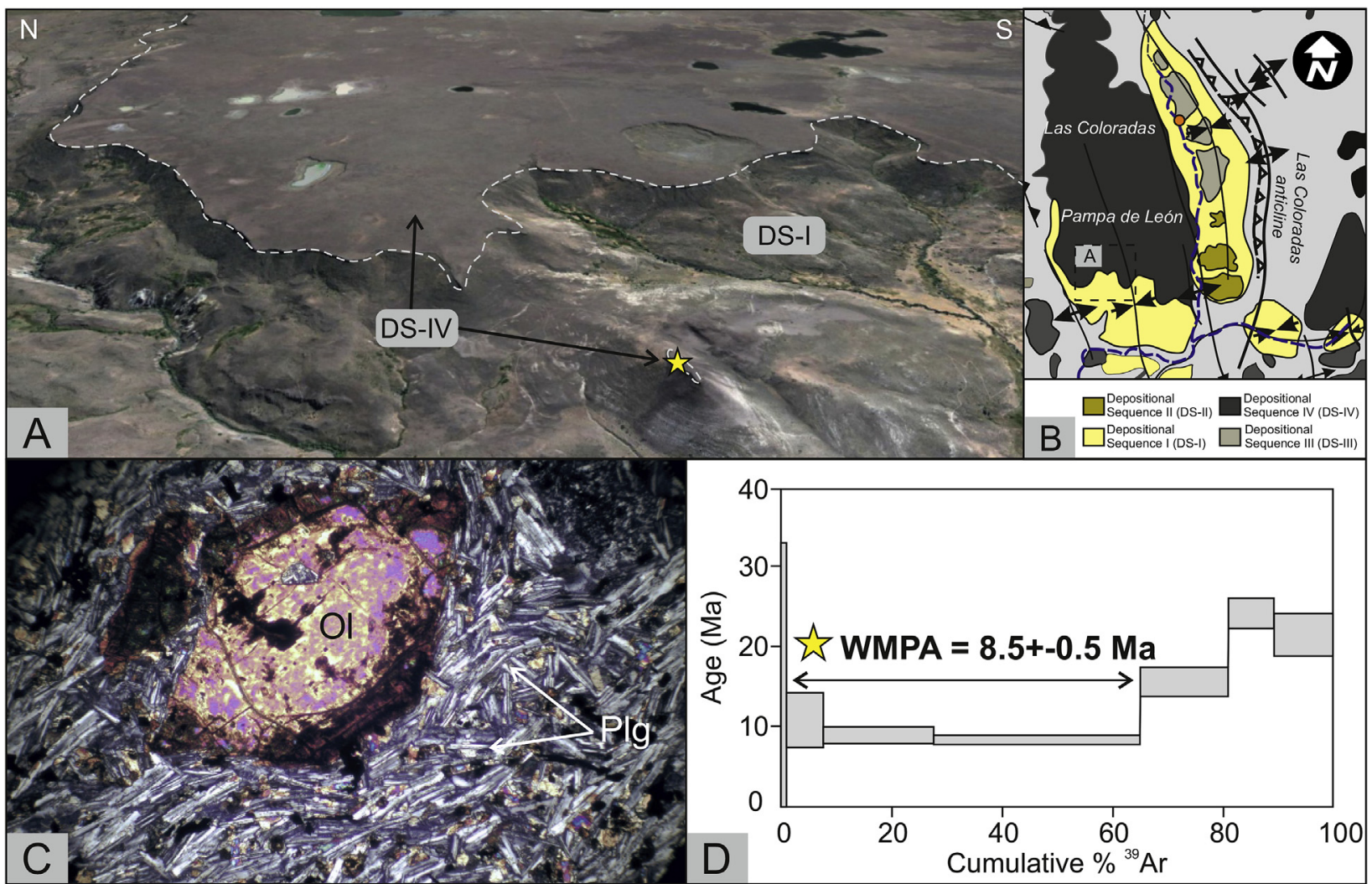

Fig. 7. a) Perspective view taken from Google Earth showing the post-kynematic, olivine basaltic lava flows of the Depositional Sequence IV in Los Remolinos subbasin. Yellow star mark the location of the geochronology sampling, b) detailed geologic map of Catán Lil basin, c) microphotograph of lava facies with olivine phenocrysts (Ol) surrounded by intersertal texture composed of small microlite of plagioclase (Plg) and olivine with minor glass participation, $(\mathrm{d}){ }^{40} \mathrm{Ar} /{ }^{39} \mathrm{Ar}$ age spectra of sample of the DS-IV (Tipilihuque Formation) calculated from fresh basalt rock of no deformed by weighted mean plateau age (WMPA) for plagioclase crystals. Data sample location: $39^{\circ} 41^{\prime} 36.30^{\prime \prime}$ S, $70^{\circ} 40^{\prime} 57.00^{\prime \prime} \mathrm{W}$, at $1046 \mathrm{~m}$ a.s.l. (For interpretation of the references to colour in this figure legend, the reader is referred to the Web version of this article.)

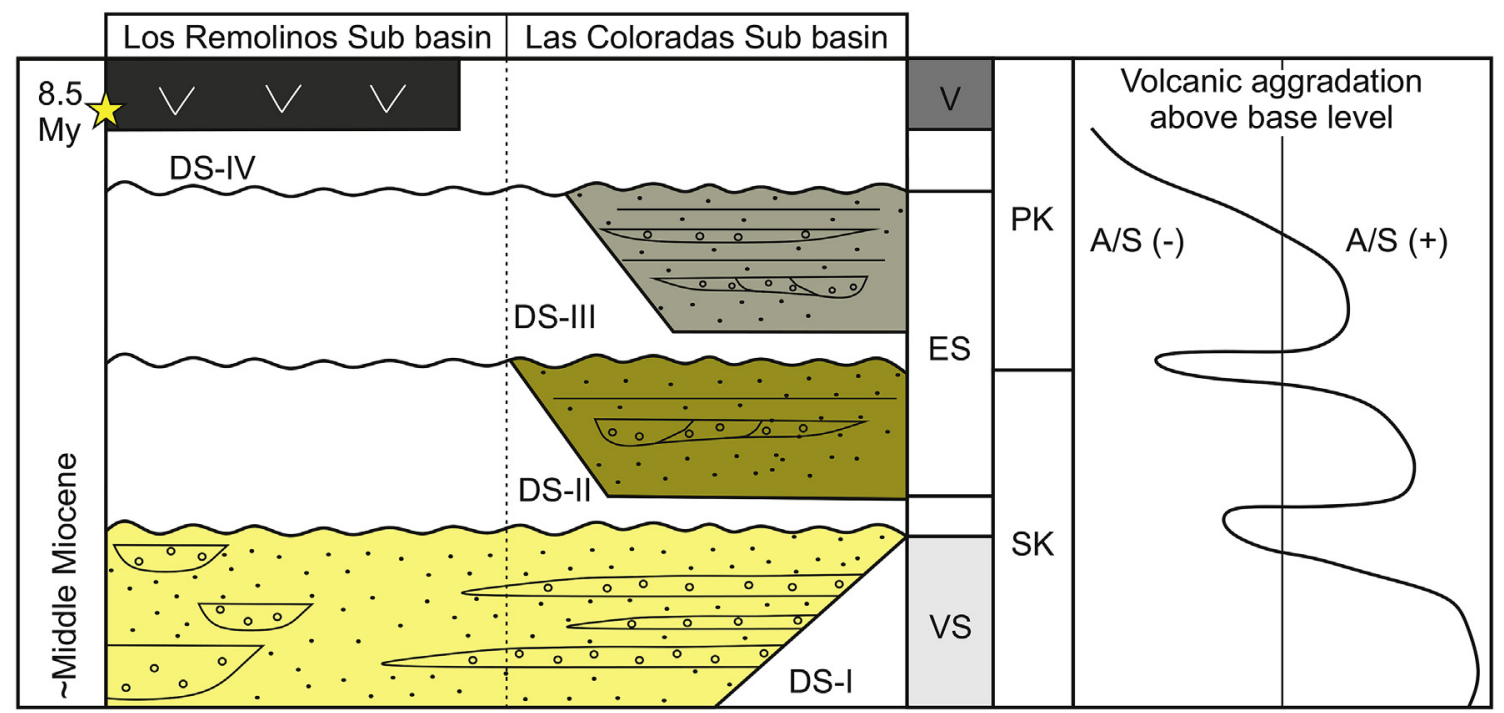

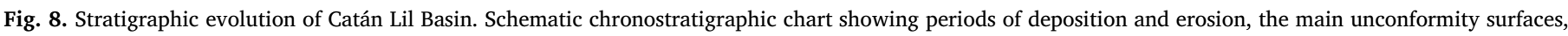

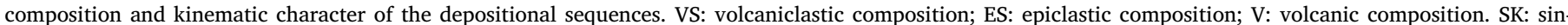

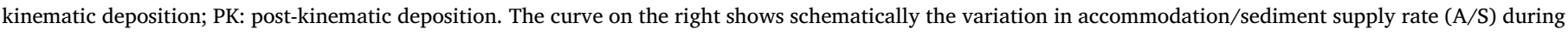
the evolution of the basin.

cycles characterized by distal alluvial plain environment and bedload fluvial system (UDS-III). At a large-scale UDS-III shows a retrogradational stacking with regards to the LDS-III. At a small scale, the sedimentary alternation of distal alluvial plain environment and bedload fluvial system may be related to the same variables that controlled this type of arrangement in the previous DS-II. In Los Remolinos sub-basin DS-II and DS-III were not recorded. This could be related with the deactivation of the sub-basin after the deposition of DS-I. 
Finally, $D S-I V$ occurred as a lava field deposited over a relatively flat geomorphological remnant surface developed over the sedimentary infill (including DS-I, DS-II and DS-III). The basaltic plateau marks the end of the depositional history of the Catán Lil Basin and the highest base level attained at the study and surrounding areas. These basalts were interpreted as the magmatic response to an extensional collapse of the North Patagonian Andes by these times (Folguera et al., 2006) marking the end of the orogenic contractional stage. The basalt lava bodies do not flowed over the high that subdivided the Catan Lil Basin, remaining confined to the Los Remolinos sub-basin. The kind volcanic forms recorded at $D S-I V$ (i.e., basaltic lava field) are capable of aggrade over the geomorphic threshold (Thouret, 1999). Thus, DS-IV has buried the pre-existent topography, instead of only to fill the available accommodation. The resistance of such volcanic rocks to erosion strongly influences the subsequent history of landscape evolution as streams penetrate into the underlying more erodible bedrock, causing a distinctive assemblage of lava-capped hills.

\subsection{The Catán Lil Basin in the context of the Andean foreland system}

The Catán Lil Basin is an alluvial-fluvial basin generated during the Miocene contractional phase of the Andean orogen. The sedimentary infill of the basin started with pyroclastic and tuffaceous vocaniclastic deposits of the DS-I. These deposits are fully correlated in all the Patagonian Broken Foreland with ages from 16.1 to 13.8 My (Marshall et al., 1977; Rabassa, 1978; Rapela et al., 1988; Mazzoni and Benvenuto, 1990; Orts et al., 2012; Bilmes et al., 2013, 2014; Ramos et al., 2014, 2015). The Miocene succession ended with basaltic lava flows of the DS-IV (Tipilihuque Formation). This basaltic plateau is part of an extensive volcanic event in the Andes of northern Patagonia that covered the sedimentary succession in several Miocene intermontane basins of the retro-arc (García Morabito et al., 2011; Ramos et al., 2014, 2015; Huyghe et al., 2014, 2015). It was constrained to the Plio-Quaternary (Cucchi y Leanza, 2005; Rojas Vera et al., 2014). Nevertheless, the geochronologic data presented in this work indicates an older, upper Miocene age (i.e., $\sim 9 \mathrm{Ma}$ ), in agreement with the ${ }^{39} \mathrm{Ar} /{ }^{40} \mathrm{Ar}$ age presented by Franzese et al. (2011) for the upper basaltic unit in the Aluminé basin, northwards of the study area. The age of this retro-arc basalt units and their occurrence were used as a guide level to define the cronostratigraphic scheme of the foreland units (e.g., Huyghe et al., 2015) or the interpretation of a different retro-arc tectonic regime to the Pleistocene (e.g., extensional retro-arc basalt; Ramos et al., 2014). Based on this chronostratigraphic constrain, the Catán Lil basin infill involved a maximum depositional lapse of $\sim 7$ My. The lower unconformity surface of $D S-I$ and the lower unconformity surface of $D S-I V$ (Tipilihuque Formation) are either physically or stratigraphically correlated within several Northpatagonian Miocene depocentres. In the Catán Lil Basin there is no evidence of contractional deformation before $9 \mathrm{Ma}$, as was registered by other authors in adjacent regions of the foreland (Huyghe et al., 2014, 2015; Niviere et al., 2014). The new age for the basaltic plateau reported in this contribution imply that the continuation of the contractional deformation in the Northpatagonian Andes into the Pliocene must be reconsidered.

The Catán Lil Basin is one of several basins with different degree of interconnection that were originated inboard of the Andean deformational front along Patagonia during the Miocene (see García Morabito and Ramos, 2012; Ramos et al., 2014, 2015). The basin was developed as an intermontane basin bounded by uplifted blocks generated by the inversion of Mesozoic normal faults (García Morabito and Ramos, 2012). This tectonic thick-skinned deformation dominates most of the retro-arc in northern Patagonia and is common in much of the Andean foreland basins that do not follow the classical model of the Foreland Basin System (see Strecker et al., 2011; Bilmes et al., 2013, 2014). Based on this tectonic framework, all Miocene retro-arc basins of the Andes at the latitude of the study area can be included into the Picún Leufú Broken Foreland (Mosquera and Ramos, 2006) or at the northern boundary of the Patagonian Broken Foreland (Bilmes et al., 2013). This scenario contrasts with the idea of Folguera et al. (2015) that suggested a flexural basin from the Andes to the Atlantic Ocean for the Miocene.

Most of the infill of the Catán Lil Basin recorded three major aggradational/degradational cycles represented by DS-I, DS-II and DS-III. Sequence boundaries between them resulted from complex valley incision and the generation of major subaerial unconformities as a result of base level falling. The sedimentary succession preserved in Catán Lil Basin can be defined as compound valley fill. The confinement of the river to the incised valley, the abundance of multi-storey sheet channels and the minor preservation of overbank fine materials indicate that the Catán Lil Basin infill occurred under general low accommodation conditions (Olsen et al., 1995; Martinsen et al., 1999). The reduction in the area of deposition between DS-I, DS-II and DS-III, the increasing amalgamation of fluvial channels towards the top of the infill and the magnitude of incision during negative accommodation stages, imply a progressive reduction of A/S during basin evolution. Aggradational/ degradational cycles could be explained in terms of tectonic cycles of orogenic loading-flexural subsidence/isostatic uplift-base-level falling (Catuneanu et al., 2011; Suriano et al., 2014). In addition, the available accommodation could have been modified by local factors, such as differential short wavelength uplift and subsidence of basement-cored blocks (see Dickinson, 1988; DeCelles, 2004; Marenssi et al., 2015), as well as by the integration and capture during the drainage network evolution.

Previous tectono-stratigraphic analysis carried out in the Patagonian Broken Foreland indicates that most of the depocentres located westwards of $68^{\circ} \mathrm{W}$ longitude evolved as disconnected depocentres (see Bilmes et al., 2013, 2014; Huyghe et al., 2015). The depositional axis of the Catán Lil Basin, as well as the recorded longitudinal fluvial system, matches with the current $\mathrm{N}-\mathrm{S}$ trace of the perennial Catán Lil River (Fig. 2a), suggesting that the current drainage network began in Miocene times, controlling the infill of the Neogene foreland system in northern Patagonia. The ending of sedimentation and infill of the Catán Lil Basin took place after the deposition of the DSIII. The occurrence of the retro-arc basaltic plateau of the DS-IV - unit that aggrade over the stratigraphic base level— amplified in time and space the infill stage of the basin. This observation has an impact in the study area as well as in the geomorphologic evolution of all the Northpatagonian foreland basin system. On one hand, DS-III marks the end of the positive accommodation space in the inner part of the foreland system around the $\sim 9 \mathrm{Ma}$. On the other, the basaltic plateau changed abruptly the conditions of the sediment routing system and amplified the falling of the base-level during the subsequent landscape evolution. Following the deposition of the basalts, a major base level falling occurred probably related to uplift of the main cordillera. This caused the incision of the Catán Lil Basin (as well as several basins of the Patagonian Broken Foreland). The total amount of base-level fall can be partly constrained to $150 \mathrm{~m}$ by the highest location of the DS-IV to the actual position of the Catán Lil River. No evidence of tectonic activity was registered in the study area during this stage. After this event, at the latitude of the study area the foreland system turned towards an erosional by-pass system, indicating that during the late Miocene a full connection with the rest of the eastern foreland areas or even with the Atlantic Ocean took place.

\section{Conclusions}

The Catán Lil Basin is an intermontane piggy-back basin developed between two anticlines associated with a west-verging thick-skinned fold-and-thrust belt, configured during a Miocene Andean contractional episode. This intermontane basin evolved as a compartmentalized basin, connected with an extrabasinal drainage network. The infill is integrated by four depositional sequences. The DS-I, DS-II and DS-III recorded three major aggradational/degradational cycles characterized by alluvial-fluvial sedimentation, with volcanicalstic to epiclastic 
sediment supply, under syn-kinematic to post-kinematic tectonic conditions. Internally to some depositional sequences cyclic arrangements between alluvial and fluvial environment were recorded. These small cycles could be interpreted as a result of autocyclic variations or climate factors. The DS-IV corresponds to basaltic lavas of the Andean retro-arc volcanism that constrain the end of deposition in the basin to the Upper Miocene $\left(8.5 \pm 0.5 \mathrm{Ma}{ }^{39} \mathrm{Ar} /{ }^{40} \mathrm{Ar}\right.$ age $)$. Based on the age of initiation of sedimentation in the foreland and a new age for the uppermost filling sequence a maximum depositional lapse of $\sim 7$ My could be determined. The ending of sedimentation of the Catán Lil Basin took place after the deposition of the DS-III. Even though, the occurrence of retroarc basaltic plateau of the $D S-I V$ amplified in time and space the infill stage of the basin.

The evolution of the basin can be fully correlated with other basins in all the Patagonian Broken Foreland with similar age and nature of the infill. The result obtained in this work may have an impact in the understanding of the tectonic, tectono-stratigraphic and geomorphologic evolution of the Northpatagonian foreland system.

\section{Acknowledgements}

This research was funded by the Agencia Nacional de Promoción Científica y Tecnológica (PICT 2013-3249 and PICT 2016-0023) and CONICET (PIP 114-2008-00632 and PIP 112-2011-00191), as well as additional financial support through a Cooperation Agreement between Pluspetrol S.A and CONICET Res.: 2391/08. Thorough and constructive reviews by Cecilia del Papa and Andrés Folguera are gratefully acknowledged.

\section{References}

Allen, P.A., Allen, J.R., 2013. Basin analysis: Oxford. Wiley Blackwell Publishing, UK, pp. 619.

Bilmes, A., D'Elia, L., Franzese, J.R., Veiga, G.D., Hernandez, M., 2013. Miocene block uplift and basin formation in the Patagonian foreland: the Gastre Basin, Argentina. Tectonophysics 601, 98-111.

Bilmes, A., D’Elia, L., Veiga, G., Franzese, J., 2014. Relleno intermontano en el Antepaís Fragmentado Patagónico : evolución neógena de la Cuenca de Gastre. Rev. Asoc. Geol. Argent. 71 (3), 311-330.

Blair, T.C., McPherson, J.G., 1994. Alluvial fans and their natural distinction from rivers based on morphology, hydraulic processes, sedimentary processes, and facies assemblages. J. Sediment. Res. 64, 450-489.

Catuneanu, O., Galloway, W.E., Kendall, C.G.StC., Miall, A.D., Posamentier, H.W., Strasser, A., Tucker, M.E., 2011. Sequence Stratigraphy: Methodology and Nomenclature. Newslett. Stratigr. 44, 173-245.

Coussot, P., Meunier, M., 1996. Recognition, classification and mechanical description of debris flows. Earth Sci. Rev. 40, 209-227.

Cucchi, R., Leanza, H., 2005. Hoja Geológica 3972-IV Junín de los Andes, provincia del Neuquén. Servicio Geológico Minero Nacional. Boletín 357, 1-102.

D'Elia, L., Muravchik, M., Franzese, J.R., Lopez, L., 2012. Tectonostratigraphic analysis of the late triassic-early Jurassic syn-rift sequence of the Neuquen basin in the Sañico depocentre, Neuquen Province, Argentina. Andean Geol. 39, 133-157.

DeCelles, P.G., 2004. Late Jurassic to Eocene evolution of the Cordilleran thrust belt and foreland basin system, western USA. Am. J. Sci. 304 (2), 105-168.

Dickinson, W.R., 1988. Provenance and sediment dispersal in relation to paleotectonics and paleogeography of sedimentary basins. In: Kle- inspehn, K., Paola, C., Pettijohn, F. (Eds.), New Perspectives in Basin Analysis. Springer-Verlag, Berlin, pp. 3-23.

Echaurren, A., Folguera, A., Gianni, G., Orts, D., Tassara, A., Encinas, A., Giménez, M., Valencia, V., 2016. Tectonic evolution of the North Patagonian Andes (41-44 S) through recognition of syntectonic strata. Tectonophysics 677-678, 99-114.

Folguera, A., Ramos, V.A., 2011. Repeated eastward shifts of arc magmatism in the Southern Andes: a revision to the long-term pattern of Andean uplift and magmatism. J. S. Am. Earth Sci. 32, 531-546.

Folguera, A., Zapata, T., Ramos, V.A., 2006. Late cenozoic extension and the evolution of the Neuquén Andes. Geol. Soc. Am. Spec. Pap. 407 407-267.

Folguera, A., Gianni, G., Sagripanti, L., Rojas Vera, E., Novara, I., Colavitto, B., Alvarez, O., Orts, D., Tobal, J., Giménez, M., Introcaso, A., Ruiz, F., Martínez, P., Ramos, V.A., 2015. A review about the mechanisms associated with active deformation, regional uplift and subsidence in southern South America. J. S. Am. Earth Sci. 64, 511-529.

Franzese, J.R., Spalletti, L.A., 2001. Late Triassic-early Jurassic continental extension in southwestern Gondwana: tectonic segmentation and pre-break-up rifting. J. S. Am. Earth Sci. 14, 257-270.

Franzese, J.R., D'Elia, L., Bilmes, A., Muravchik, M., Hernández, M., 2011. Superposición de cuencas extensionales y contraccionales oligo-miocenas en el retroarco andino norpatagónico: la Cuenca de Aluminé, Neuquén, Argentina. Andean Geol. 38, 319-334.
García Morabito, E., Ramos, V.A., 2012. Andean evolution of the Aluminé fold and thrust

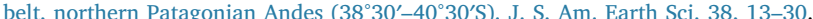

García Morabito, E., Gotze, H., Ramos, V.A., 2011. Tertiary tectonics of the Patagonian Andes retro-arc area between $38^{\circ} 15^{\prime}$ and $40^{\circ} \mathrm{S}$ latitude. Tectonophysics 499, 1-21.

Giacosa, R.E., Heredia, N., 2004. Structure of the North Patagonian thick-skinned fold and-thrust belt, southern central Andes, Argentina (41-42 S). J. S. Am. Earth Sci. 18 (1), 61-72.

Gianni, G., Navarrete, C., Orts, D., Tobal, J., Folguera, A., Giménez, M., 2015. Patagonian broken foreland and related synorogenic rifting: the origin of the Chubut Group Basin. Tectonophysics 649, 81-99.

Gibling, M.R., 2006. Width and thickness of fluvial channel bodies and valley fills in the geological record: a literature compilation and classification. J. Sediment. Res. 76, 731-770.

Gulisano, C.A., Gutierrez Pleimling, A.R., Digregorio, R.E., 1984. Esquema estratigráfico de la secuencia jurásica del oeste de la provincia del Neuquén. In: 9 Congreso Geológico Argentino. San Carlos de Bariloche, Actas, pp. 236-259.

Huyghe, D., Nivière, B., Bonnel, C., 2015. Geomorphologic evidence for Plio-Quaternary shortening in the southern Neuquén basin (40 S, Argentina). Terra. Nova 27 (6), 426-432.

Huyghe, D., Bonnel, C., Nivière, B., Fasentieux, B., Hervouët, Y., 2014. Neogene tectonostratigraphic history of the southern Neuquén basin ( $39^{\circ}-40^{\circ} 30^{\prime} \mathrm{S}$, Argentina): implications for foreland basin evolution. Basin Res. 27 (5), 613-635.

Kelly, S.B., Olsen, H., 1993. Terminal fans - a review with reference to Devonian examples. Sediment. Geol. 85, 339-374.

Legarreta, L., Uliana, M.A., 1996. The Jurassic succession in west-central Argentina: stratal pattern, sequences and paleogeographic evolution. Paleogeogr. Paleoclimatol. Paleoecol. 120, 303-330.

Major, J.J., Janda, R.J., Daag, A.S., 1996. Watershed disturbance and lahars on the east side of Mount Pinatubo during the mid-June 1991 eruptions. In: Newhall, C.G., Punongbayan, R.S. (Eds.), Fire and Mud, Eruptions and Lahars of Mount Pinatubo, Philippines. University of Washington Press, Seattle, pp. 895-919.

Manville, A.V., Nemeth, K., Kano, C., 2009. Source to sink: a review of three decades of progress in the understanding of volcaniclastic processes, deposits, and hazards. Sediment. Geol. 220, 136-161.

Marenssi, S.A., Ciccioli, P.L., Limarino, C.O., Schencman, L.J., Diaz, M.Y., 2015. Using fluvial cyclicity to decipher the interaction of basement-and fold-thrust-belt tectonics in a broken foreland basin: vinchina Formation (Miocene), Northwestern Argentina. J. Sediment. Res. 85 (4), 361-380.

Marshall, L.G., Pascual, R., Curtis, G.H., Drake, R.E., 1977. South American geochronology: radiometric time scale for middle to late tertiary mammal-bearing horizons in Patagonia. Science 195, 1325-1328.

Martinsen, O., Ryseth, A., Helland-Hansen, W., Flesche, H., Torkildsen, G., Idil, S., 1999. Stratigraphic base level and fluvial architecture: Ericson Sandstone (Campanian), Rock Springs Uplift, SW Wyoming, USA. Sedimentology 46, 235-259.

Mazzoni, M.M., Benvenuto, A., 1990. Radiometric ages of tertiary ignimbrites and the Collón Cura formation, Northwestern Patagonia: XI congreso geológico Argentino, San Juan. Actas 87-90.

Miall, A.D., 1996. The Geology of Fluvial Deposits. Sedimentary Facies, basin Analysis and Petroleum Geology. Springer, Berlin, pp. 582.

Mosquera, A., Ramos, V.A., 2006. Intraplate deformation in the Neuquén embayment. Geol. Soc. Am. Spec. Pap. 407, 97-123.

Nivière, B., Bonnel, C., Huyghe, D., Aubourg, C., Callot, J.P., Hoareau, G., Brannelec, M., Krim, N., Brito, D., Ringenbach, J.C., 2014. Neogene and Quaternary Evolution of the Neuquen Foreland (Argentina). VIII INGEPET, pp. 15.

Olsen, T., Steel, R., Hogseth, K., Skar, T., Roe, S.L., 1995. Sequential architecture in a fluvial succession: sequence stratigraphy in the Upper Cretaceous Mesaverde Group, Price Canyon, Utah. J. Sediment. Res. B65 (2), 265-280.

Orts, D.L., Folguera, A., Encinas, A., Ramos, M., Tobal, J., Ramos, V.A., 2012. Tectonic development of the North Patagonian Andes and their related Miocene foreland basin $\left(41^{\circ} 30^{\prime}-43^{\circ} \mathrm{S}\right)$. Tectonics $31,1-24$.

Patton, T.L., 2004. Numerical models of growth-sediment development above an active monocline. Basin Res. 16, 25-39.

Rabassa, J., 1978. Estratigrafía de la región de Pilcaniyeu-Comallo, Provincia de Río Negro. In: 7 Congreso Geológico Argentino, Buenos Aires, Actas. vol. 1. pp. 731-746.

Ramos, M.E., 2013. Controles tectónicos de las principales secuencias volcano-sedimentarias del Cenozoico en la Cordillera Nordpatagónica. Doctoral dissertation, Facultad de Ciencias Exactas y Naturales. Universidad de Buenos Aires.

Ramos, M.E., Folguera, A., Fennell, L., Gimenez, M., Litvak, V.D., Dzierma, Y., Ramos, V.A., 2014. Tectonic evolution of the North Patagonian Andes from field and gravity data $\left(39-40^{\circ}\right.$ S). J. S. Am. Earth Sci. 51, 59-75.

Ramos, M.E., Tobal, J.E., Sagripanti, L., Folguera, A., Orts, D.L., Giménez, M., Ramos, V.A., 2015. The North Patagonian orogenic front and related foreland evolution during the Miocene, analyzed from synorogenic sedimentation and U/Pb dating ( $42^{\circ}$ S). J. S. Am. Earth Sci. 64, 467-485.

Rapela, C., Spalletti, L., Merodio, J., Aragon, E., 1988. Temporal evolution and spatial variation of early Tertiary volcanism in the Patagonian Andes (40S-42 30 's). J. S Am. Earth Sci. 1, 75-88.

Ré, G.H.,S., Geuna, M.G., López, Martínez, 2000. Geoquímica y geocronología de los basaltos neógenos de la región de Aluminé (Neuquén-Argentina). In: 9 Congreso Geológiaco Chileno, Puerto Varas, Actas. vol. 2. pp. 62-66.

Rodolfo, K.S., Umbal, J.V., Alonso, R.A., Remotigue, C.T., Paladio-Melosantos, M.L., Salvador, J.H.G., Evangelista, D., Miller, Y., 1996. Two years of lahars on the western flank of Mount Pinatubo: initiation, flow processes, deposits, and attendant geomorphic and hydraulic changes. In: Newhall, C.G., Punongbayan, R.S. (Eds.), Fire and Mud: Eruptions and Lahars of Mount Pinatubo, Philippines. University of Washington Press, Seattle, pp. 989-1013. 
Rojas Vera, E., Sellés, D., Folguera, A., Gímenez, M., Ruíz, F., Orts, D., Ramos, V.A., 2014. The origin of the Loncopue Trough in the retroarc of the Southern Central Andes from field, geophysical and geochemical data. Tectonophysics 637, 1-19.

Scott, W.E., Hoblitt, R.P., Torres, R.C., Self, S., Martinez, M.M.L., Nillos, T., 1996. Pyroclastic flows of the June 15, 1991, climactic eruption of mount Pinatubo. In: Newhall, C.G., Punongbayan, R.S. (Eds.), Fire and Mud, Eruptions and Lahars of Mount Pinatubo, Philippines. PHIVOLCS Press, Quezon City, and University of Washing- ton Press, Seattle, pp. 545-570.

Shanley, K.W., McCabe, P.J., 1994. Perspectives on the sequence stratigraphy of continental strata. AAPG (Am. Assoc. Pet. Geol.) Bull. 78, 544-568.

Smith, G.A., 1986. Coarse-grained nonmarine volcaniclastic sediment- terminology and depositional process. Geol. Soc. Am. Bull. 97, 1-10.

Smith, G.A., 1991. Facies sequences and geometries in continental volcaniclastic sediments. In: Fisher, R.V., Smith, G.A. (Eds.), Sedimentation in Volcanic Settings. Special Publication SEPM (Society Economic Paleontolo- gists and Mineralogists), Tulsa, pp. 109-121.

Strecker, M.R., Hilley, G.E., Bookhagen, B., Sobel, E.R., 2011. Structural, Geomor- phic, and depositional characteristics of contiguous and broken foreland basins: examples from the Eastern Flanks of the Central Andes in Bolivia and NW Argentina. Tectonics of Sedimentary Basins. John Wiley \& Sons, Ltd 508-521.

Suriano, J.,C.O., Limarino, A.M., Tedesco, M.S., Alonso, 2014. Sedimentation Model of Piggyback Basins: Cenozoic Examples of San Juan Precordillera. Geological Society London, Argentina, pp. 221-244 Special Publications 399.

Thouret, J.C., 1999. Volcanic geomorphology a review. Earth Sci. Rev. 47, 95-132. Turner, J.C.M., 1976. Descripción geológica de la Hoja 36a, Aluminé, provincia del Neuquén. Servicio Nacional Minería Geología. Boletín 145, 1-65.

Vattuone, M.C. Latorre, 1998. Caracterización geoquímica y edad K/Ar de basaltos del Terciario superior de Aluminé, Neuquén. In: Congreso Latinoamericano de Geología, No. 10, Buenos Aires, Actas. vol. 2. pp. 184-190.

Vergani, G.D., Tankard, A.J., Belotti, H.J., Weisink, H.J., 1995. Tectonic evolution and paleogeography of the Neuquen basin, Argentina. In: In: Tankard, A.J., Suarez, S.R., Welsink, H.J. (Eds.), Petroleum Basins of South America 62. AAPG Memoir, pp. 383-402.

Wright, V.P., Marriott, S.B., 1993. The sequence stratigraphy of fluvial depositiona systems: the role of floodplain sediment storage. Sediment. Geol. 86, 203-210. 